\section{Helsetjenestens juridiske sider}

\author{
Molven 0 .
}

Helse og jus

En innføring for helsepersonell. 6. utg. $434 \mathrm{~s}$.

Oslo: Gyldendal Akademisk, 2009. Pris NOK 450 ISBN 978-82-05-39430-8

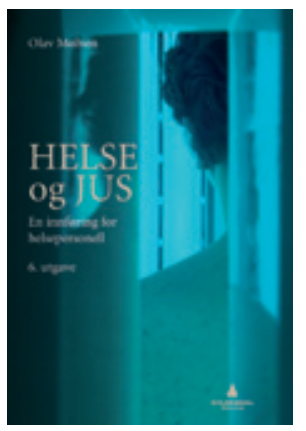

Helsepersonellets og helsetjenestens virksomhet er i de senere år i utstrakt grad blitt regulert gjennom ny lovgivning. Helse og jus gir en innføring i en rekke juridiske emner som berører helsetjenesten.

Boken presenterer juridisk tenkemåte og metode. Lovbestemmelsene relateres til konkrete problemstillinger. Denne sjette utgaven av boken er ajourført mht regelverk og viktige avgjørelser fra domstoler og andre myndighetsorganer frem til våren 2009. Forfatteren oppgir som målgrupper studenter i helsefag, helseadministrasjon og -ledelse, og helsepersonell som møter helserettspørsmål i praksis.

Boken omhandler omfattende temaer som: helsepolitikk, etikk og helserett; befolkningens rett til helsehjelp; pasientens rett til informasjon og selvbestemmelse; krav til helsepersonellet og helsevesenet; ledelse av virksomhet og fordeling av myndighet; kravet om internkontroll; skader og uhell; dokumentasjon og journal; taushetsplikt og samarbeid. En grundig presentasjon, med eksempler hentet fra offentlige dokumenter og dommer bl.a.

En kunne ønske at en så innsiktsfull forfatter hadde gitt noen systemkritiske kommentarer av og til. Regelverket er nå så omfattende at spørsmålet om hensiktsmessighet melder seg. Temaet byråkrati har ikke fătt noen selvstendig plass i boken, men byråkratiet har jo delvis vokst som følge at et mer omfattende regelverk. Forfatteren går systematisk gjennom begrepet forsvarlighet. Men i praksis benyttes begrepet også som en unnskyldende klisje. Regelverket vedrørende pasientansvarlig lege er redegjort for. Men fungerer ordningen hensiktsmessig?

Folketrygdens omfattende regelverk er kursorisk omtalt i Helse og jus. Spesialisthelsetjenestelovens syketransportforskrift er ikke nevnt i det hele tatt. Arbeidsmiljøloven som berører helsepersonells arbeidsforhold og yrkesutøvelse i så mange henseende, er ikke nevnt. Utvalget av rettsregler behandlet i denne boken er noe mer helseledelsens og -myndighetenes regelperspektiv, enn det er perspektivet til helsepersonell med pasientkontakt.

Boken har både en kortfattet innholdsoversikt og en detaljert innholdsfortegnelse. Fremstillingen er oversiktlig, og i et forståelig språk. Stikkordregisteret er for begrenset i forhold til de mange relevante emner som er omtalt i teksten. Boken inneholder en god oversikt over lover, forskrifter, offentlige dokumenter og relevant juridisk litteratur.

\section{Rolf Hanoa}

Nevrokirurgisk avdeling

Oslo universitetssykehus, Ullevål

\section{Til å bli klok av}

Bugge KE, Røkholt EG.

\section{Barn og ungdom som sørger}

Faglig støtte til barn og ungdom som opplever alvorlig sykdom eller død i nær familie. 206 s, ill. Bergen: Fagbokforlaget, 2009. Pris NOK 298 ISBN 978-82-450-0762-6

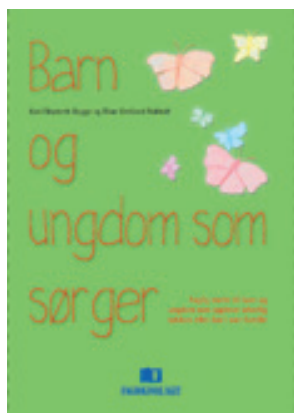

Som det fremkommer i undertittelen er dette en bok beregnet på voksne som arbeider med barn eller ungdom i barnehage, skole, SFO eller på ulike nivåer i helsetjenesten. Det vil si samtlige yrkesgrupper som møter foreldre og barn som pårørende og etterlatte $i$ krise og sorg. Betydningen av en tverrfaglig/-etatlig samhandling er også understreket.

De to forfatterne er henholdsvis sykepleier og pedagogisk-psykologisk rådgiver. Etter å ha arbeidet klinisk og med forskning og utviklingsarbeid i mer enn 15 år med familier i tider med sykdom og etter forventet eller brå $\mathrm{d} ø \mathrm{~d}$, fungerer de nå som henholdsvis leder og spesialrådgiver ved Seksjon for sorgstøtte ved Akershus universitetssykehus.

I sju velredigerte kapitler beskrives mangfoldet ved barns og ungdoms reaksjoner og behov i et utviklings- og mestringsperspektiv, gjennom boken også beskrevet $i$ en rekke gode eksempler, ofte med sitater fra samtaler med barn og ungdom. Teksten belyser ytterligere hvor ulikt hverdagsliv, prestasjoner og væremåte kan påvirkes av sykdom og død. Her er også omtale av arbeid med barn og unge med spesielle behov bl.a. fra familier med etnisk minoritetsbakgrunn.

Det gis en god og oversiktlig beskrivelse av metoder for å støtte barn og ung som pårørende og som etterlatte. Intervensjoner for å skape trygghet, refleksjon, kroppskontroll, forståelse og emosjonell kontroll er kort beskrevet. Likeså gis det eksempler fra foreldreveiledning, familiesamtaler, lekeog samtaleterapi. Sorgstøttetilbudet ved A-hus synes å være et glimrende eksempel på et helhetlig tilbud. Der inngår både familiesamtaler, sorggrupper for barn og unge bla basert på alder eller spesielle behov, foreldregruppe, besteforeldre- og nettverkstreff og samling for førskolelærere og lærere.

Barns rettigheter er godt omtalt med henvisning til gjeldene politiske føringer, lover, regler og en oversikt over nyttige linker og nettsteder. Fortsatt er det mye ugjort på dette feltet, ikke minst innen psykisk helsevern for voksne når det gjelder å kartlegge om pasientene har barn, skaffe informasjon om hvordan barna har det og sikre at barn blir tilstrekkelig ivaretatt.

Litteraturlisten er omfattende med en rekke henvisninger til norske arbeider, men også til relevante internasjonale publikasjoner. Forfatterne skriver at de bevisst har unngått å lage et stikkordregister fordi de ønsker at leseren skal «lete etter helhetlig meningsforståelse og ikke etter enkelte søkeord». Dette er helt i tråd med de holdninger og kunnskaper de presenterer i denne boken som trygt kan anbefales til kollegene. Den bør kunne inngå som pensum i en rekke helsefag.

Inger Helene Vandvik

Slependen 